\title{
LINGUISTIC EXPRESSION WITH REFERRENCE TO SEMIOTIC IN ULOS OF WEDDING CEREMONY OF BATAK TOBA
}

\author{
*Hendro Doglas Simamora \\ **Prof. Dr. Zainuddin, DIP. TEFL., M.Hum \\ **Prof. Dr. Hj. Sumarsih, M.Pd
}

\begin{abstract}
Hendro D. Simamora. 2123220017. Linguistic Expression with Reference to Semiotic in Ulos of Wedding Ceremony of Batak Toba. A Thesis.English and Literature Department.Faculty of Languages and Arts.State University of Medan. 2017

This study was deal with linguistic expression, in semiotics of ulos in wedding ceremony of bataktoba. This research used qualitative method which concerned with developing explanations of experience or on data. The source of the data was taken from the ulosin wedding ceremony of batak toba, and relevant with the transcript of interviewing by three informants with some criterias, that is the most dominant population in three different surename in Tarutung, at the age of 45 to 55 years old and have the recognition from each surename. The instruments that is used in this study was tape recorder, camera, and also the book which relevant to the data. In technique of analyzing data, descriptive qualitative data analysis stage is identifying the ornament, reducing the ornament which are not relevant, classifying, interpreting, analyzing and concluding the findings. There are three kinds of ulos used in wedding ceremony of BatakToba, they are ulosragidup, ulosragihotang, and ulossadum. Each ulos have topisokkar which explain that everything in this world have the limit and the color depend to the ceremony that is performed. In ulosragidup, there are hatirsymbolized of wealth, sigumang symbolized the hope of the giver of this ulos for the receiver to works right and efficient also, batuniansimun symbolizing the health, sisikniikansymbolizing a good life, tidy life, even in a crowded of life, and alsojungkit symbolizing in having an organized life well. In ulosragihotangthere are unok-unok, symbolized be a wise person like the humus, andjungkit. In ulossadum, there is torna where this symbol to remind the people that Batak people come from mountain.
\end{abstract}

Keywords: Semiotic, Ulos in Wedding Ceremony of BatakToba, Ornaments. 


\section{INTRODUCTION}

\section{Background of the Study}

Finegan (2008: 22) states linguistics is the study of these knowledge systems in all their aspects: how is such a knowledge system structured, how is it acquired, how is it used in the production and comprehension of messages, how does it change over time. Linguistics analyzes human language as a system for relating sounds (or signs in signed languages) and meaning. Linguistic structures are pairings of meaning and form. Linguistics has many sub-fields concerned with particular aspects of linguistic structure that is phonetics, phonology, morphology, syntax, semantics, pragmatics, discourse analysis, stylistics, and semiotics.

Porcar (2011:22) states semiotics is usually defined as the study of signs. Semiotics appears to be a paradoxical discipline, meaning we find it all around us and, yet, nowhere specifically. Semiotic is important in our daily life, because our life is full of semiotic system which we have learn and understand it unconsciously. It is a behavior of society to make something have their own value, even sometimes semiotic will make some different perspective, but the goal would be to explore the

meaning for something better in future. Semiotics is closely related to the field of linguistics, which, for its part, studies the structure and meaning of language more specifically. The semiotic tradition explores the study of signs and symbols as a significant part of communications. 
In Batak culture there are some characteristics which is become their identity such as tor-tor, gorga, song, ulos, and many more. One of the most popular characteristic of Batak culture is ulos. Ulos is a heritage from the ancestor, and be trusted have the supernatural power.

"Ulosconsidered as a blessed thing by supernatural power. If ulosmade by a certain patern, ulos can be use as a preceptor in our life" (Takari, 2009:12).

Sitompul (2009) states many kinds of ulos by the type, design, and function, such as ulosjugia which contain with a high culture value, and also with a high price. Ulosjugia have a function as prosperity and used by the old people who have the grandchild from all their son and daughter. Ulossadum is another kinds of ulos, which usually used in happy ceremony, and also as souvenir. UlosRagihotang is an ulos which symbolize as have a trong body, strong soul, and strong faith, and many more kinds of ulos.

Takari (2009:13) states ulos has many ornaments form that show their characteristic, includes color, length, arts, etc. The weaver created something not only for looking beauty, ulos also contain the different message each other, a sincere and glorious hope. Ulos have some functions in daily life of Batak people, that is : as clothes, as scarf, as headband, as waist fastener, as carrying cloth, and as a symbolize in sacred ceremony. 


\section{REVIEW OF LITERATURE}

The study is completed with theories correlated to the topic researched in order to enhance the knowledge toward the topic. The theories are consisted of linguisticexpression,semiotics and ulos.

A Linguistic Expression is any physical form (sound, visual image or sequence thereof) used to represent a linguistic unit. Linguistic expressions are objects. A linguistic expression may be spoken, written, or signed. A linguistic expression is distinct form the actual process (speaking, writing, signing) that produces the expression. In communication, a speaker sends a fixed meaning to a hearer via the linguistic expression associated with that meaning.

Lakoff\& Johnson (1980:206) states meanings are objects and linguistic expressions are objects. Linguistic expressions have meanings (in them). In communication, a speaker sends a fixed meaning to a hearer via the linguistic expression associated with that meaning. On this account it is possible to objectively say what you mean, and communication failures are matters of subjective errors: since the meanings are objectively right there in the words, either you didn't use the right words to say what you meant or you were misunderstood.

Goes from theory above, it can be concluded as the study of language in order to get the relation among language and ulos related each other. 
The semiotic related to the system and code to have the symbol each other. When the system and code related to literary work, they have a process to communication between reader to literary work and writer.

Zoest (1991:80) states Saussure called his theory as the main of structuralism ideology. Saussure said that the basic of linguistic explanation depart on two dimension of thinking, or pair of clashing, that is dichotomy between lanque and parole, and dichotomy between signifier and signified.

Semiotic is divided into two parts; the form which the sign takes (a signifier) and the sign / the concept it represents (the signified). Markers seen as a form / physical form, can be known through the work of architectural form, is being seen as a sign of meaning is revealed through the concept, function and / or values contained in works of architecture. The existence of Saussure's semiotics is the relation between signifier and signified according to convention, commonly said as significance. Significance semiotic is the system of sign which learn about elements in a system based on specific rules or conventions.

Tambunan (1982) states ulos is a specific characteristic of Batak in their culture as one of ethnics in Indonesia which obey on the manners hereditarily, especially in Batak Toba. Ulos is a special cloth which be woven with their own motif. The motive and colors have a special meanings also, and we can't use it randomly in every ceremony, like in birthday party, or another ceremony except the birth moment, wedding, and die ceremony. 


\section{RESEARCH METHODOLOGY}

\section{Methodology}

This research used qualitative method. Windridge (2009:6) states qualitative research is concerned with developing explanations of social Phenomena, focuses on reports of experience or on data which cannot be adequately expressed numerically. It means that this research produce descriptive data.

The source of the data was taken from the ulosin wedding ceremony of batak toba which taken from the weaver in Tarutung, and relevant with the transcript of interviewing. Based on ulosBatak reference written by Sitompul (2009), there are three kinds of ulos that is used in wedding ceremony of Batak Toba, namely ulosRagidup, ulosRagihotangand ulosSadum. This statement also relevant to the result of interviewing in Tarutung that the researcher conducted it. In order to be able to understand the ornaments of ulos, the researcher applied 3 informants to conduct the interview, with some criterias, that is :

1. The most dominant population in three different surename in Tarutung, which the data was taken from the headman of Tarutung

2. At the age of 45 to 55 years old

3. Have the recognition from each surename.

\section{DATA AND DATA ANALYSIS}


As it has been mentioned in the previous chapter, this study deal with the language expression with reference to semiotic in ulos of wedding ceremony of bataktoba. The data were the ornament in ulos that is used in wedding ceremony of bataktoba. The data analyzed by identifying the ornament in ulos of wedding ceremony of bataktoba and described the ornament into language.

After the data have been collected, it can be interpreted that the linguistic expression in ulos of wedding ceremony of batak toba.

1. Kinds of Ornament in Ulos of wedding ceremony of Batak Toba

There weretendifferent types of ornaments in ulos of wedding ceremony of batak toba, they are :

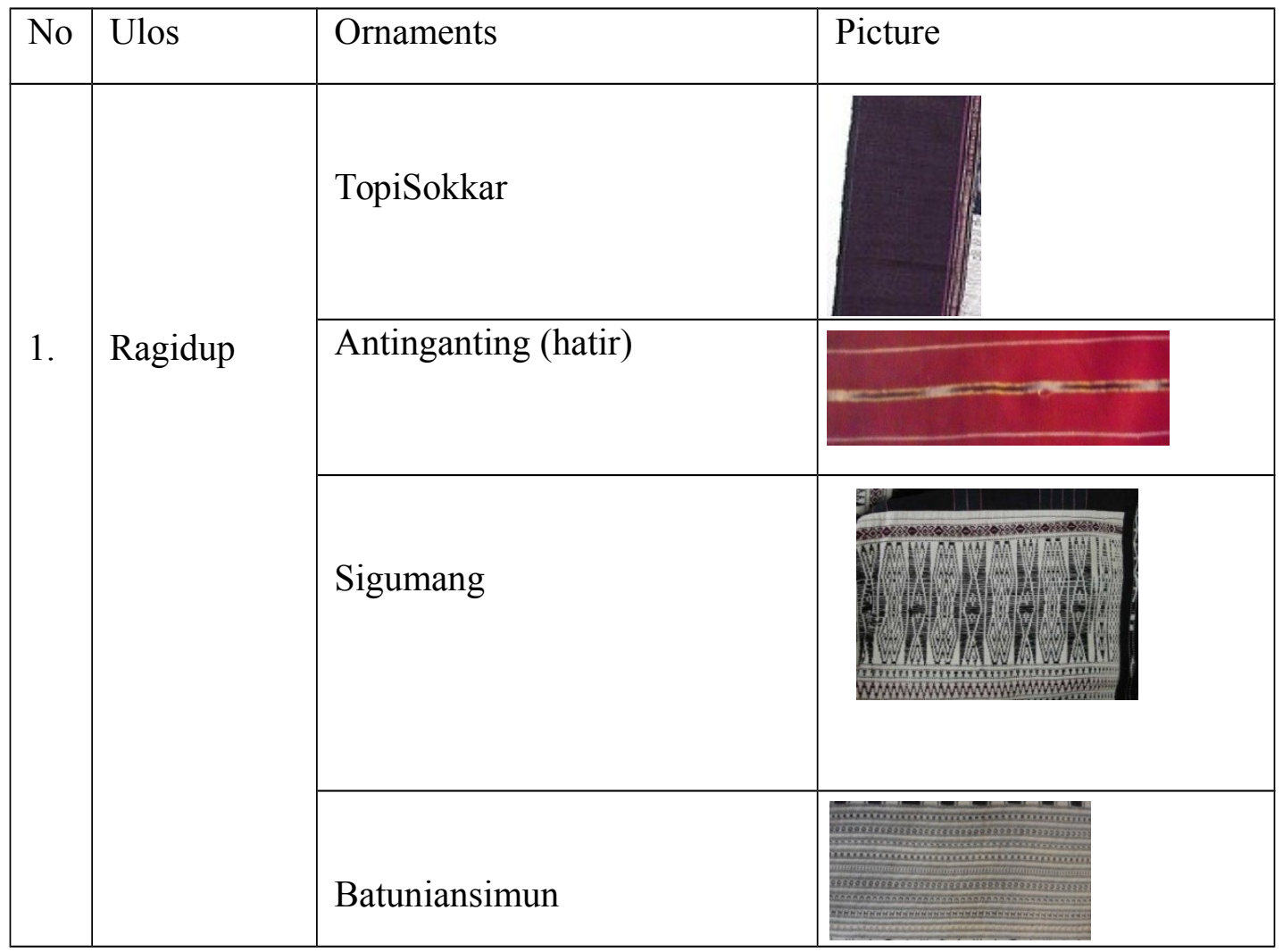



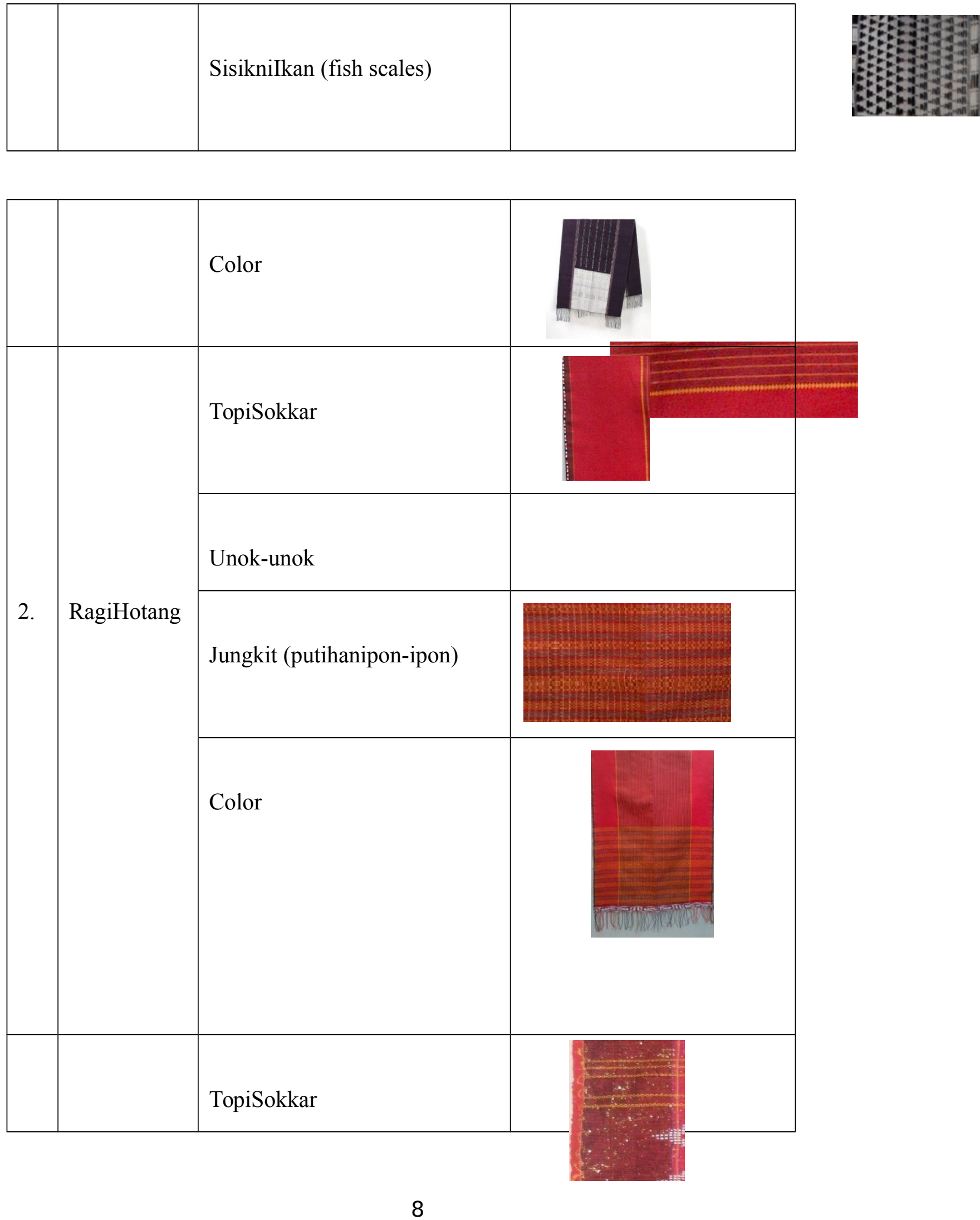


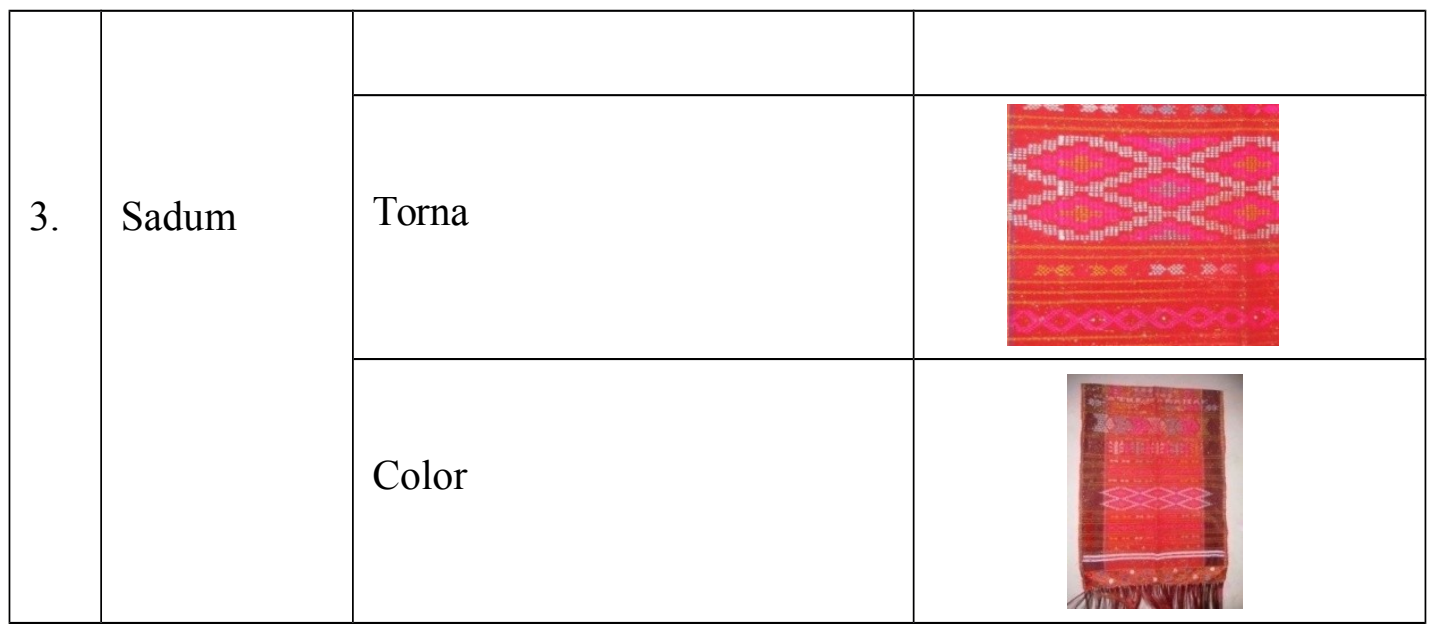

2. Meaning of each ornaments in Ulos of wedding ceremony of Batak Toba

\begin{tabular}{|l|l|l|}
\hline No & Ornaments (Signifier) & Meaning (Signified) \\
\hline 1. & TopiSokkar & $\begin{array}{l}\text { This ornament found on both sides of each ulos, } \\
\text { which made as the border or the line of each ulos in } \\
\text { making the ulos. This ornament explain that } \\
\text { everything in this world have the limit. }\end{array}$ \\
\hline 2. & Antinganting (hatir) & $\begin{array}{l}\text { This ornament found in UlosRagidup, and usually } \\
\text { made of gold. But in this era, gold just as the color } \\
\text { in this ulos cause of the price of gold is very } \\
\text { expensive. This ornament is the symbol of wealth, }\end{array}$ \\
\hline 3. & $\begin{array}{l}\text { Sigumang } \\
\text { cause made of gold. }\end{array}$ \\
\hline & $\begin{array}{l}\text { Sigumang means bear, where in Batak land, bear } \\
\text { is an animal that works right and efficient. } \\
\text { Sigumang symbolized the hope of the giver of }\end{array}$ \\
\hline
\end{tabular}




\begin{tabular}{|l|l|l|}
\hline 4. & Batuniansimun & $\begin{array}{l}\text { this ulos for the receiver to works right and } \\
\text { efficient also. This symbol just found in } \\
\text { ulosRagidup. }\end{array}$ \\
$\begin{array}{ll}\text { Ansimun means cucumber, where this kind of } \\
\text { this vegetable is easy in grow up. Cucumber is } \\
\text { good for health. So, this ornament symbolizing } \\
\text { the hope of health, and could be grow up where } \\
\text { ever we are. This symbol also just found in } \\
\text { ulosRagidup. }\end{array}$ \\
\hline 5. & $\begin{array}{l}\text { Shis symbol looks like fish scale. Fish is one of } \\
\text { symbol in Batak culture, and as a media in } \\
\text { giving the expectance, pray and dream. Fish } \\
\text { usually life in crowded and well-run. Beside it, } \\
\text { the fish scale also organized and tidy. So, this } \\
\text { symbol is a hope and pray for the people who } \\
\text { receive this ulos, in getting a good life, tidy life, } \\
\text { even in a crowded of life. This symbol just } \\
\text { found in ulosRagidup. }\end{array}$ \\
\hline $\begin{array}{l}\text { In Batak culture, there are 3 colors which } \\
\text { represent the Batakbelief, they are Red, } \\
\text { White and Black. Red means the heroism and }\end{array}$ \\
bolor
\end{tabular}




\begin{tabular}{|c|c|c|}
\hline & & $\begin{array}{l}\text { prestigious, but usually means as sorrow. But } \\
\text { lately Yellow (Gold) include in Batak belief, } \\
\text { which means as wealth and fertility. So, in } \\
\text { Ulos also can be divided into } 2 \text { color, they are } \\
\text { bright which use in happy ceremony, and } \\
\text { dark which use in mourning ceremony. }\end{array}$ \\
\hline 7. & Unok-unok & $\begin{array}{l}\text { Unok similar with humus, in growing of } \\
\text { plants well. In ulos, unok-unok just found in } \\
\text { ulosRagihotang which used by a man. It } \\
\text { means, the man has a responsibility and be } \\
\text { expected in giving the new generation, and be } \\
\text { a wise person like the humus to help another } \\
\text { in growing up well. }\end{array}$ \\
\hline 8. & Jungkit (putihanipon-ipon) & $\begin{array}{l}\text { Jungkit means a thing to get something. This } \\
\text { symbol can be found in ulosRagidup. Jungkit } \\
\text { also called as putihanipon-ipon, where ipon is } \\
\text { teeth in English. The people without teeth are } \\
\text { less attractive. Teeth is organized well, so this } \\
\text { symbol is a hope for the people who receive }\end{array}$ \\
\hline
\end{tabular}




\begin{tabular}{|l|l|l|}
\hline 9. & $\begin{array}{l}\text { this ulos in having an organized life well, and } \\
\text { this symbol also as something to beautify the } \\
\text { ulos and make it interesting. }\end{array}$ \\
\hline which used by the woman. Tor means \\
mountains. Batak people come from \\
mountain. So, this symbol looks like a \\
mountain, to remind the people that Batak \\
people come from mountain. This symbol \\
also just as something to beautify the ulos.
\end{tabular}




\section{CONCLUSION AND SUGGESTIONS}

\section{Conclusions}

After analyze the data, the conclusion are :

1. There are nine kinds of ornament in ulos of wedding ceremony of Batak Toba. the kind of ornament in ulos of wedding ceremony is called as signifier. Signifier is the formwhich the sign takes.

2. The meaning of each ornament, have the different meaning each other. The meaning from each ornament is called as signified. signified is the sign /the conceptit represents.

\section{Suggestions}

Based on the conclusion above, it's advisable that:

1. In learning a language as the social semiotics will give us the contribution to find more system of using sign in society, because life is full of semiotic system, like events, feelings, objects, etc., which we have learn and understand it unconsciously

2. For the readers, is better to understand the ornament in ulos especially in wedding ceremony of Batak Toba, so they will know the semiotics meaning of ulos that is used in wedding ceremony of Batak Toba, and to preserve our culture especially ulosof Batak Toba as one of the heritage of Indonesia. 
3. For other researcher, this study can be used as reference in analysis another ulos, in another ceremony of Batak Toba.

\section{REFERENCES}

Berger, Arthur Asa. 2005. Sign in Contemporary Culture AnIntruduction to Semitic AlihBahasa M. DwiMarianto. Tanda-TandadalamKebudayaan Kontemporer; SuatupengantarSemiotika.Jogjakarta.TiaraWacana.

Chandler, D. (2007). Semiotics The Basics. Canada: Routledge.

Cobley, P. (2005).The Routledge Companion to Semiotics and Linguistics. Canada: Routledge.

Danesi, Marcel. (2004). Message, Signs, and Meanings.Canada : AGMV Marquis Imprimeur Inc.

Davis, A. (2004). The Handbook of Applied Linguistics.USA: Blackwell Publishing.

Dostert, George (2009). The Study of Language: An Introduction. Cambridge: Cambridge University Press.

Finegan, E. (2008). Language : Its Structure and Use. USA: West Group.

Hancock, B. (2009). An Introduction to Qualitative Research. Nottingham: University of Nottingham.

Harianja, R. (2013). PamanatDenggan. Medan: CV.MITRA.

Kumar, K. (1989). Conducting Key Informant Interviews in Developing Countries.USA: Agency for International Development.

Lakoff, G. and M. Johnson. (1980). The Journal of Philosophy. London: The University of Chicago Press.

(2003). Metaphors We Live By. London: The University of Chicago Press.

Leeuwen, T.V. (2005). Introducing Social Semiotics.Canada :Routledge.

Meyer, Charles.F. (2009). Introducing English Linguistic.UK : Cambridge University Press.

Panggabean, R. (2009). Sadum : Traditional and Contemporary. Bandung. 
Pardede, R. (2010). Masisean di UlaonAdat.Medan.

Pardosi, J. (2008). MaknaSimbolikUmpasa, Sinamot, danUlospadaAdat PerkawinanBatak Toba. Medan.

Porcar, C. (2011). Sign and Meaning: A Semiotic Approach to Communication. France: Babes-Bolyai University.

Rivkin, Julie. (2004). Literary Theory : An Anthology.UK : Blackwell Publishing.

Salzmann, Z. (1998). Language Culture and Society: An Introduction to Linguistic.USA : Westview Press.

Saragih, A. (2014). Variations and Functional Varieties of Language. Medan.

Sebeok, T. A. (2001). Signs: An Introduction to Semiotics. Canada: University of Toronto Press Incorporated.

Siburian, H.A. (2014). A Brief Introduction to Sociolinguistics.Medan : Faculty of Languages and Arts State University of Medan.

Sitompul, R.H.P. (2009). UlosBatak Tempo Dulu-MasaKini. Jakarta: KERABAT.

Smith, P. (2009). Cultural Theory An Introduction. USA : Blackwell Publishing.

Takari, M. (2009).UlosdanSejenisnyadalamBudayabatak Toba di Sumatera Utara: Makna, Fungsi, danTeknologi. Malaysia: Universiti Malaya.

Windridge, Kate. (2009). An Introduction to qualitative Research.Leicester : NIHR RDS East Midlands

Zoest, A.Z. (1996). Serba-serbiSemiotika. Jakarta: GramediaPustakaUtama. 